\title{
CESIS
}

Electronic Working Paper Series

Paper No. 36

\section{FDI Inflows to Sweden Consequences for Innovation and Renewal ${ }^{1}$}

\author{
Börje Johansson and Hans Lööf
}

(JIBS/CESIS and CESIS)

August 2005

Centre of Excellence for Science and Innovation Studies http://www.infra.kth.se/cesis Corresponding author: hansl@infra.kth.se

\footnotetext{
${ }^{1}$ Status of the paper: The paper will be published in a forthcoming book volume.
} 


\title{
FDI Inflows to Sweden- Consequences for Innovation and Renewal
}

\author{
Börje Johansson* and Hans Lööf
}

August 2005

\begin{abstract}
FDI inflows have expanded rapidly during the past decade. This paper analyses if such inflows do introduce new characteristics of the innovation systems at national and regional levels. The paper studies two phenomena. First, what novelties are brought into the host region (country) when FDI inflows occur? Second, what are the consequences for the innovation intensity, technology transfer and economic performance of firms in a regional (national) economy that experiences FDI inflows? These issues are assessed by examining the characteristics of foreign multinationals and comparing them with the characteristics of multinational, uninational and non-affiliate firms, respectively. The analyses control for location, examine regional impacts, and are based on CIS data (Community Innovation Survey III). The paper contributes to earlier studies in two important ways. First, it compares FDI firms with three other distinct types of corporate structure. Second, it combines results from both parametric and non-parametric estimations. The results indicate that FDI inflows in an unambiguous way renew the local economy when acquiring or replacing domestic multi-unit firms (uninationals). Compared to other types of corporate structure, FDI firms do not seem to improve innovation characteristics of the local economy.
\end{abstract}

Keywords: FDI, technology transfer , innovation, regional economy

JEL codes: C21, D21, F23, L23, R11

\footnotetext{
* Economics, JIBS, Box 1026, 55111 Jönköping and Department for Transport and Economics, The Royal Institute of Technology, 10044 Stockholm, email: borje.johansson@ihh.hj.se

- Department for Transport and Economics, The Royal Institute of Technology, 10044 Stockholm, email: hansl@infra.kth.se
} 


\section{INTRODUCTION}

Why should a firm decide to have several establishments located in different regions and countries? We may also ask why the number and expansion of multinational firms have increased for several decades. Antras and Helpman (2003) argue that the expansion of FDI flows reflects a growing specialisation of production. The main mechanism for FDI is merger and acquisition (M\&A), and since the late 1980s the cross border share of total M\&A has been relatively constant (United Nations, 2000). Hence, the tendency og multi-location solutions is as strong within countries as it is between countries.

Dunning (1977) suggests that a multi-location firm has specific assets that gives it an advantage over potential competitors in a given region. In addition, the location of a subsidiary in a given region must also provide some advantage that is not obtained if the firm were exporting from some "home location". Extending this argument, the assumption is that a lack of markets for firm-specific assets, including various forms of knowledge, provides the individual firm with incentives to internalise production and other supply activities in owned subsidiaries abroad (Caves, 1982; Braunerhjelm, 1999). Because of this and with reference to Coase (1937), a firm may decide to penetrate a foreign market by means of direct investments instead of forming agreements to cooperate with firms in the foreign market, including licensing arrangements.

When a multinational firm makes a direct investment in a foreign market it establishes an FDI firm in that market. In view of the discussion above, how will an FDI firm influence the knowledge flows, the R\&D intensity and R\&D collaboration in the local economy where the FDI firm is located? In what other ways may it influence the host-country and host-region economy? In general we refer to the consequences for a regional as well as national economy as "local economy effects".

A basic observation has stimulated the research efforts in this paper. The observation is that multinational firms are network organisations. As such a multinational firm has geographically (globally) spread information and knowledge sources. An individual FDI firm can draw on all this information, and hence it has the potential of introducing more novelties than a non-multinational domestic firm. Even when an new FDI firm is established through a merger with or acquisition of a domestic multinational firm, the new network would be enlarged. In this latter case the counteracting force is that headquarter decisions move out of the host country. 
The network in which an FDI firm is an integral part could also make the firm more productive and innovative, with sales that to a large extent are based on product innovations. When the latter is the case, novelties will penetrate the local economy.

It has been conjectured that the establishment of an FDI firm in an economic environment brings novelties to the same local economy (Aitken and Harrison and Lipsey, 1999). These novelties can be in the form of new production techniques, new products and new market networks, and the novelties may as a consequence improve productivity and profitability in the local economy (Keller, 2004). The FDI firms may be more productive than the existing average firm. In addition, they may influence the environment in several other ways, such as delivering inputs with better quality and higher performance characteristics to local firms. They may also stimulate product development among local firms when they act as input customers. In addition they may, in a less direct way, diffuse technology to the local milieu of firms.

There are clear reasons to contemplate the influence that FDI firms can have in their local economic environment. Normally they belong to large multinational concerns with extensive $R \& D$ programmes. In recent time a lot of their innovation activities have become decentralised to subsidiaries abroad, i.e., to FDI firms. Kuemmerle (1999) reports for five OECD countries how the share of R\&D carried out outside the firm's home country has increased from 6.2 percent in 1965 to almost 26 percent in 1995. Similar observations can be found in Zander (1994) and Cantwell (1998).

Obviously, FDI firms are gradually becoming more R\&D intensive in their own right. The effect of this can be an impulse to innovations and economic renewal in the region where an FDI firm locates and in the pertinent country. In a previous paper the authors examine how multinational firms influence innovation activities in a set of Swedish geographical areas (Johansson, Lööf and Rader-Olsson, 2005). In that study a careful distinction is made between effects on the innovation behaviour that are associated with (i) different attributes of a firm and (ii) any additional region-specific characteristic. The outcome is that there are certain additional regional effects (See also Ebersberger and Lööf, 2005).

The present study employs basically the same data set (2086 firms) ${ }^{2}$ for Sweden as in Johansson, Lööf and Rader-Olsson (2005), but now with a specific focus on FDI firms. Sweden is divided into three geographical areas: Stockholm, West Sweden and the rest of Sweden. The first of these areas can be classified as a proper functional (metropolitan) region 
with proximity externalities, the second contains a metropolitan region but comprises also other functional regions, and the third area (rest of Sweden) provides a base for reference. The paper contributes to existing knowledge by systematically comparing FDI firms with other corporate structure classifications. It should be observed that the study comprises firms in both manufacturing and service industries.

In the empirical analysis and econometric models we investigate the R\&D and knowledge intensity, sector and size distribution and a series of innovation characteristics of FDI firms, while controlling for location. Moreover, the interaction of FDI firms with local innovation systems is investigated as well as the relative importance of FDI inflows for the establishment of new firms. Especially, we compare FDI firms with other categories of firms with regard to innovation results, type of innovation and methods to privatise the knowledge assets that FDI firms build up. In the analysis of the regional economic milieu and how FDI firms affect this, we primarily employ descriptive statistics to compare the Stockholm metropolitan region with the other two geographical areas.

Section 2 presents an overview of how FDI flows have developed internationally and for Sweden. It reviews existing theories of FDI incentives and the effects of FDI decisions. The section also provides a discussion of the role that FDI firms can play with regard to technology transfers and knowledge flows.

Section 3 presents the data source of the study and specifies the different variables that are used in the analyses. On the basis of descriptive statistics, the section continues by examining how FDI firm characteristics vary across regions and how FDI firms in general differ from other firms in Swedish economy.

In Section 4 we carry out a series of regression analyses. The tool is a two-step probit model, with results that allow for more precise conclusions than in Section 3. The econometric analysis is followed up by a matching approach in Section 5, where FDI firms are systematically compared with non-affiliate, uninational and domestic multinational firms. Section 6 contains concluding remarks, including a discussion of the Swedish innovation policy in view of FDI inflows.

\footnotetext{
${ }^{2}$ The difference in sample sizes is explained by a merger of CIS data and register data in Johansson, Lööf and Rader-Olsson, which had the negative consequence that 170 observations had no matching observations in the register data.
} 


\section{POTENTIAL ECONOMIC IMPACTS OF FDI}

\subsection{FDI, Globalisation and the Swedish Economy}

Since 1990 the world-wide production in firms located outside the owner's country of residence has increased from 6 to 11 percent of world output (UNCTAD, 2002). The increase in Sweden has also been large as recorded in Table 1.

Table 1: Development of FDI-firm activities in Sweden 1995 and 2001

\begin{tabular}{|lll|}
\hline FDI firms' role in Sweden & $\mathbf{1 9 9 5}$ & $\mathbf{2 0 0 1}$ \\
\hline FDI firms' share of manufacturing output & $20.7 \%$ & $33.9 \%$ \\
FDI firms' share of total R\&D investments & $20.7 \%$ & $40.7 \%$ \\
FDI firms' share R\&D man-years & $20.1 \%$ & $40.3 \%$ \\
Number of FDI firms & 3300 & 7800 \\
\hline
\end{tabular}

Source: ITPS (2005a)

In 2001 a considerable share of manufacturing output in Sweden had FDI firms as a source, and more than 40 percent of all R\&D efforts in Sweden took place in FDI firms. The growth of the number of FDI firms between 1995 and 2001 is also considerable and signals that the domestic economy of Sweden is strongly integrated in the global economy. The latter is accentuated if we add that more than 50 percent of the private employment in Sweden can be found in foreign and domestic multinationals. Data for 2003 show that around half of the export from Sweden originated from FDI firms and the corresponding figure for imports to Sweden was 59 percent (ITPS, 2005b). This latter observation implies that on average FDI firms have a higher export and import intensity than domestic firms.

Foreign direct investments (FDI) in OECD countries like Sweden have primarily the form of acquisitions, where foreign multinationals expand their network of production, sales and R\&D units and locate them as FDI firms across a set of countries (Lipsey, 2002). In Sweden the globalisation of MNE networks is reflected by a change from 3300 foreign-owned firms in the middle of the 1990s to 7800 in the beginning of the 2000s.

The described development is not particular for Sweden. Around 90 percent of the global FDI stock in 2003 was owned by OECD multinationals, and more than 70 percent of the FDI flows were directed towards OECD countries (UNCTAD, 2004). All this reflects a global network formation for business decisions and knowledge flows. Obviously, this will have an impact on how the international economy will function and develop. But what is the impact on technology diffusion and development in the Swedish economy and its different regions? 


\subsection{FDI Incentives and Consequences}

What are the motives of a firm that decides to make a foreign direct investment? An answer to this question is provided in the OLI framework, as suggested by Dunning (1977). In this framework an FDI firm tries to simultaneously exploit three advantages, namely ownership, location and internalisation advantages. An ownership advantage is based on firmspecific assets that may spring from innovations in the form of successful products and superior production techniques, but also knowledge and skill assets of the firm.

Internalisation of a firm's proprietary assets is essential, since it represents a way to ripe the potential returns to the firm-specific assets. Internalisation means that the firm keeps control of the use of its assets by establishing firm units in many locations, thereby capturing a larger economic rent based on its assets. When such locations are in other countries, the firm is multinational.

In addition there should be something to gain from establishing a facility in a specific location - in another country. In the OLI context the facility may be a production unit or a subsidiary firm that organises the contact with the local market (market motive). The incentive to locate a production unit could be that the selected location can offer superior or cheaper resources (resource motive).

The above framework is often interpreted in a static and narrow way, disregarding that a firm is not only a supplier and producer, buying inputs, producing and selling its output. Potentially a firm is also carrying out development and innovation activities, which may lead to changes in output attributes, new routines of production and distribution and design of interaction patterns with new customers (Johansson, 2005).

In the recent literature on FDI firms the perspective is different from the focus in the OLI model. The shift in perspective is an increased interest in technology transfer associated with the establishment of FDI firms, as well as the knowledge base and productivity of these firms. Elements of this new focus goes all the way back to Dosi (1988), Porter (1990) and Nelson (1992) and in this context the conjecture is that FDI firms can be an important part of the local innovation systems of a region, and that they can enrich the regional innovation processes through a local diffusion of knowledge flows that spring from their own global networks. These aspects are emphasised in Jaffe et.al (1993), Audrecht and Feldman (1996), Kuemmerle (1999) and Cantwell and Janne (1999).

We have seen in Table 1 that FDI firms in Sweden carry out a fair amount of the R\&D investments in Sweden. Still, there are clear empirical indications saying that multinational 
firms are reluctant to reallocate their R\&D forts to their FDI firms. The latter are more often used in production, sales activities and marketing. The lion part of R\&D seems to stay in the home country of each multinational firm (Narula, 2002). Contributions by Freeman (1992), Ehrnberg and Jacobsson (1997) and Narula (2002) argue that this can be explained by each firm's embeddedness in innovation systems at home.

\subsection{FDI, Technology Transfers and Knowledge Flows}

This study aims at examining if the location of an FDI firm in an urban region adds new features to the region. We must then ask: what features are particular to an FDI firm. As an instrument for this discussion we will make use of the distinction between (i) proximity externalities and (ii) network (or link) externalities (Johansson, 2005).In view of this we observe that urban proximity means that firms can benefit from mutual proximity and that makes the costs of distance-sensitive transactions lower and reduce costs of all sorts of interaction. Hence, it affects how firms can interact via the market and how they can influence each other outside the market with regard to non-pecuniary information and knowledge flows.

The proximity-based reduction of transaction costs generates an externality that affects both the input and output side of a firm. When proximity is not at hand, two interacting firms can make a joint link investment that can help to reduce transaction and other interaction costs also over long distance (Johansson and Quigley, 2004). Such link investments are in general economically sound only when a transaction link is used frequently. At the same time we observe that economic links between firms are more easy (less costly) to establish between firms that are located in the same functional region, again due to lower interaction costs.

A multinational firm is different from other firms, because it consists of a mother firm and a set of interlinked FDI firms. At the same time, the location of each FDI firm is based on a decision to make use of proximity externalities in the regional milieu where it is placed. This feature of combining proximity and link externalities has implications for the supply activities of the FDI firm. However, there should also be consequences with regard to the firm's development activities.

The foreign multinational firm decides to place an FDI firm in a particular location, because it expects to gain something by being in that region. The performance of supply activities may improve due to interaction with input suppliers and customers in the local context. In addition, such interaction may generate pure knowledge spillovers but also stimulate to joint R\&D efforts. 
In view of the last observation, the FDI firm may also get advantages related to its development activities. The firm may gain from information about (i) preferences and technology of local customers, (ii) technology of competitors as well as input suppliers, and (iii) R\&D efforts of competitors, input suppliers and customers. A FDI firm may also benefit from pure knowledge spillovers from the innovation systems in the regional milieu (Johansson, 2005). One may conjecture that these flows of information and knowledge that occur in a regional context may cover information with relevance for the entire country to which the region belongs.

Having made all these observations, there is an additional and important question. Do the firms in a region benefit anything from getting an FDI firm as a neighbour? Are there positive feedbacks from the FDI firm to the innovation and development processes of the existing firms in the region (and country)? What are the reasons for asking this kind of question? First, an FDI firm may get involved in knowledge transactions with actors in its location. Second, in the course of its interaction with suppliers, customers and knowledge providers the firm could benefit from (non-pecuniary or pure) knowledge spillovers. Third, the FDI firm can bring novelties into the local economy by bringing demand for new product attributes into the local market place as well as supplying equipment and services with new attributes.

In this study the first two aspects will be elucidated by examining a set of FDI-firm characteristics and compare them with the characteristics of three different categories of hostcountry firms: (i) non-affiliate firms (single-establishment firms), (ii) uninational firms (multi-establishment firms that are not multinational), and (iii) domestic multinationals . By matching the FDI firms against these two categories of firms, it becomes possible to reveal to what extent the FDI firms bring novelties into the economy. The matching analysis will comprise comparisons of the following set of innovation activity attributes:

- Introduction of new firms (newly established)

- $\quad$ Scientific collaboration within the innovation system

- Vertical collaboration within the innovation system

- Horizontal collaboration within the innovation system

- Collaboration in global innovation networks

- Orientation towards product innovation

- Orientation towards process innovation

- Innovation that is novel (non-imitation) in nature

- $\quad$ R\&D intensity

- Innovation sales, i.e., sales of new products. 


\section{THE ROLE OF FDI-FIRMS IN THE SWEDISH ECONOMY}

\subsection{Data Sources for the Empirical Analysis}

This study uses data from the Community Innovation Survey (CIS) III for Sweden. The survey was conducted in 2001 and it covers the period 1998-2000. The observations cover both the manufacturing and business services sector. The sample contains 2086 firms of which half are identified as innovative firms.

The CIS allows for broad comparisons across firms and countries. However, its usefulness in analyses of regional aspects is somewhat limited. Firms are for instance not asked to report on the proximity of their domestic collaboration on innovation with external partners. The reporting units are firms, whose geographical locations are known, but R\&D and production activities in establishments located in other geographical areas will also be included in the data that refers to the reporting unit. In order to reduce - but not eliminate - these problems, we have disaggregated the Swedish economy into three large regional areas. In addition, we have assumed that the firms' establishments as well as their collaboration in innovation processes, mostly are limited to the same geographical areas as the reporting firm.

\subsection{Variable Description}

In the analysis we employ the selection variable "innovative firms", which refers to firms that report one or several of the following events during the most recent 3-years period: (i) product innovation, (ii) process innovation and (iii) innovation efforts. The study considers five different categories of innovation characteristics. For each such category, the study explores its relationships to a set of determinants. The five categories of characteristics are defined as follows: (i) innovation input measures the firms' expenditures on R\&D and other innovation activities per employee, (ii) embeddedness in the domestic science base is a composite dummy variable indicating if the firms is collaborating with universities, and private and public R\&D laboratories, (iii) embeddedness in the domestic vertical innovation system is a composite variable indicating if the firms collaborate on innovation with customers and suppliers and (iv) embeddedness in the domestic horizontal innovation system is supposed to capture a firm's collaboration on innovation with competitors or consultancies. The firth category, global innovation network, refers to innovation collaboration with actors outside Sweden.

The study makes use of two different measures of the firms' output performance. The first is non-imitation innovations, which is a dummy variable that indicates if a firm has introduced a product which is partly or completely new to the market. The second measure is 
innovation sales, that is, sales revenue from new products. The variable innovation sales is expressed in intensity terms (per employee).

Findings by Kuemmerle (1999), Crisculo et al. (2002), Ebersberger and Lööf (2005) and others indicate that corporate structure has an influence on innovative activities and location. In our study FDI firms are separated from firms with other corporate structure and compared with non-affiliate enterprises (firms not belonging to a group), uninational enterprises (firms belonging to a group with only domestic affiliates), and domestic multinationals

The main firm characteristics in the study are firm size, human capital (university educated/total employment), physical capital, knowledge capital (current and recurrent R\&D), product and process innovation. In addition a firm can be (i) newly established, but also the result of a merger or an acquisition. In order to control for industry-specific factors, six sector dummies are included in the analysis, as well as information about the firm's most significant market (local, national or global). The variable list is presented in the Appendix (Table A).

In the empirical analysis we examine the role of FDI firms across corporate structure and across geographical areas. The spatial decomposition of the Swedish territory is described in Table 2 this specification allows us to control for firm location and to detect if the Stockholm region affects innovativeness in any particular way.

Table 2: The three geographical areas in the study

\begin{tabular}{|ll|}
\hline Region & Defintion \\
\hline Stockholm & Stockholm county \\
West Sweden & Västra Götaland and Halland counties \\
Rest of Sweden & All remaining counties \\
\hline
\end{tabular}

The first region corresponds to Stockholm metropolitan region, whereas West Sweden includes both Gothenburg metropolitan region and three other medium-sized urban regions. The area "Rest of Sweden" is used as a reference area for comparisons.

In the matching processes we employ additional information that is not included in Table A and 3.1. The new information classifies protection methods that each firm uses as means to keep its intellectual property secret of private. These protection methods that are presented in Table 3.9 include (i) patent applications, (ii) patent possessions, (iii) registration of patented design, (iv) copyright, (v) secrecy, (vi) complexity of design, and (vii) lead-time advantage.

As a final overview information we present in Table 3 the distribution of corporate structures across regions. The table shows how the firms in the sample are distributed, and we may conclude that the sample has a fairly proportional distribution with regard to corporate 
structure. The only exception is the overrepresentation of domestic MNEs in the Stockholm region.

\subsection{Spatial Distribution of Technology Groups and Knowledge Intensity}

The main objective of this sub section is to examine how the Stockholm region differs from the other two geographical areas in Sweden. We will investigate the distribution across the three areas with regard to the size of firms, the number of firms in different sectors, knowledge and R\&D intensity of firms, the frequency of newly established firms, and the intensity of innovation-system collaboration.

This type of examination will partly reveal to what extent the Stockholm region offers FDI firms and firms in general another type of economic milieu than the other parts of Sweden. In simple terms: can FDI firms benefit more from a location in Stockholm and reciprocally, can Stockholm region benefit more than other regions from FDI inflows? Inspecting these descriptive statistics generates information about the need to control for firm location when we proceed to the econometric analyses in subsequent sections.

As regards the size of firms, there is only one spatial characteristic. Measuring the number of persons employed, Swedish multinationals in the Stockholm region are larger than elsewhere in the country. The distribution of industry sectors is on the other hand quite particular in Stockholm, with a composition that reveals a higher knowledge intensity than elsewhere. This is illustrated in Table 4, where we can detect a disproportionately high share of high-tech manufacturing and knowledge-intense services. In addition, the firm entry is much higher in the Stockholm region, measured as the share of newly established firms.

Table 3.3 indicates strongly that the Stockholm region is a more knowledge oriented economic milieu than other parts of Sweden. This feature can be further demonstrated by examining the set of innovative firms across regions. These firms have positive R\&D expenditures, have introduced new products or carried out process innovations.

Table 5 shows that the Stockholm region has a high share of the employment with university education (human capital), a comparatively high R\&D intensity (R\&D expenditures per employee), and a high ratio of innovation sales to total sales.

An examination of how firms collaborate in the innovation systems shows that the distribution is roughly the same across regions. In summary we have seen that compared with other parts of Sweden, Stockholm is more knowledge intensive, has a higher R\&D intensity 
and has a higher entry rate of new firms. All this tells us that it is important to control for location in the econometric work in subsequent sections.

\subsection{Comparison of FDI-Firms with other Firms}

In this section we start to compare FDI firms with other types of firms with regard to a technology classification of sectors and with regard to firm entry for all firms, including those classified as non-innovative. Thereafter the comparison is between innovative firms, classified with regard to corporate structure.

Table 6 shows that FDI firms have a disproportionately high representation of highmedium technology manufacturing and a contrasting low share of low technology manufacturing. Hence, they differ from Swedish multinationals which in particular are characterised by a high share of high technology manufacturing. Hence, the observations in Table 6 imply that our subsequent econometric exercises should control for sector. We also observe that non-affiliate firms have a disproportionately high share of knowledge-intensive producer services.

The second type of questions asked relate to how firms are established and whether they are classified as innovative. Table 7 shows that FDI firms are characterised by a larger than proportional entry rate. They are also established through merger and acquisition more often than proportionately. Finally, they are classified as innovative at higher than proportional rate.

If we limit the description to the subset of innovative firms, we can conclude that FDI firms are slightly less knowledge intensive than other firms, have a lower R\&D intensity than other firms, but have a slightly higher share of innovation sales than non-affiliate and uninational firms. All this is illustrated in Table 8.

Having described the knowledge and R\&D intensity of FDI firms, we may consider their collaboration with actors in the scientific, vertical, horizontal and global innovation systems. Descriptive statistics in this case indicate that FDI firms collaborate more intensively than non-affiliate and uninational firms, but less than domestic multinationals. Swedish multinationals are characterised by having much higher collaboration share than all other categories. This conclusion is especially clear with regard to vertical and global innovation interaction (Table 9).

Table10 reveals that there is no bias among FDI firms with regard to the share of product and process innovations, and non-imitation innovations. However, among FDI firms there is a higher degree of knowledge protection than among non-affiliate and uninational firms. The highest share of firms with knowledge protection is found for Swedish MNEs. 


\section{ECONOMETRIC ANALYSES OF INNOVATIVE FDI FIRMS}

\subsection{Estimation Model}

Section 4 analyses how the innovation behaviour of firms is affected by their corporate structure, which provides a comparison between FDI firms and other categories of firms. We use an econometric model as a means to control for region, sector and the distinction between firms that are innovation active and those that are not. The additional determinants are corporate structure and firm characteristics. As a tool we apply a two-step estimation procedure, with a generalized Tobit model, comprising the selection equation (1) and a performance-equation (2). This model is consistently estimated by means of full maximum likelihood techniques, using observations on both innovative and non-innovative firms.

The estimation procedure aims to solve the econometric problem of selection bias. Our approach takes into account that not all firms are engaged in innovative activities. When only the innovation sample is used in some part of the model, the firms are not randomly drawn from the larger population, and selection bias may arise. The two-step model used in the analyses accounts for this possible problem by formulating the following choice structure. In the first step firms decide whether to engage in innovation activities or not (selection equation). Given that a firm has decided to invest in innovation projects, the 8 different performance variables are estimated. More specifically, we are using the following model:

$$
\begin{aligned}
& y_{0 i}=\left\{\begin{array}{lll}
1 & \text { if } \quad y_{0 i}^{*}=X_{0 i} \beta_{0}+\varepsilon_{0 i}>0 \\
0 & \text { if } \quad y_{0 i}^{*}=X_{0 i} \beta_{0}+\varepsilon_{0 i} \leq 0
\end{array}\right. \\
& y_{1 i}=y_{1 i}^{*}=X_{1 i} \beta_{1}+\varepsilon_{1 i} \text { if } y_{0 i}=1
\end{aligned}
$$

where $y_{0 i}^{*}$ is a latent innovation decision variable measuring the propensity to innovate, $y_{0 i}$ is the corresponding observed binary variable being 1 for innovative firms and zero for others. $y_{1 i}$ signifies the 8 performance variables. $X_{0 i}$ and $X_{1 i}$ are vectors of various variables explaining innovation decision and innovation performance. The $\beta$-vectors contain the unknown parameters for each equation. $\varepsilon_{0 i}$ and $\varepsilon_{1 i}$ are independent and identically distributed drawings from a normal distribution with zero mean, jointly correlated. 
In the next two sub sections we present results based on eight regression equations. For all these case, the selection equation shows that the probability of being and innovative firms is positively influenced in a clearly significant way (1\%) by (i) firm size, (ii) sales per employee, (iii) merger and acquisition, (iv) knowledge intensity, (v) national and global market extension. All together, the selection equation has 14 determinants.

\subsection{Innovation Behaviour}

In this subsection we analyse variables that affect an individual firm with regard to $R \& D$ intensity and collaboration in the scientific, vertical and horizontal information systems. Results from these regressions are specified in Table 11.

The R\&D intensity may be considered as the most important indicator here, since we want to know if FDI firms add to the local R\&D intensity. Most of the results are straightforward. The sector classification has a significant impact. Moreover, the R\&D intensity is positively influenced by persistent R\&D, process innovation and negatively by firm size. There is no region-specific effect. Finally, corporate structure has an affect: All other things equal Swedish multinational have a higher R\&D intensity and FDI firms have not.

Another way that FDI firms can fuel the innovation processes in the local economy is by participating actively in the various innovation systems. Our reference is the innovationsystem participation of uninational firms. Everything else equal, Swedish multinationals interact with higher frequency with actors in all three innovation systems (scientific, vertical and horizontal). With regard to the vertical innovation system, the parameter for FDI firms is positive and significant. So is the parameter for non-affiliate firms.

The conclusion is that our regression model cannot detect any strong indication of specific effects from FDI inflows on R\&D intensity and on innovation-system activities, except for vertical innovation collaboration, where FDI firms are more likely to collaborate than uninational firms.

\subsection{Type of Innovation and Returns to Innovation Efforts}

So far we have seen that FDI firms do not seem to intensive the interaction within the scientific and horizontal innovations networks in Sweden. And FDI firms are not more FDI intensive than non-affiliate and uninational firms. FDI firms might influence innovation processes by having more product innovations of more process innovations than other firms. Regression equation (5) and (6) in Table 4.2 provides answers to this latter question. 
With regard to product innovations we find that FDI firms, Swedish multinationals and non-affiliate firms all have more frequent product innovations than uninational firms, as indicated by equation (5) In addition, the probability of product innovations is higher in the Stockholm region than elsewhere in Sweden.

Turning to process innovations, FDI firms are nott associated with a higher innovation probability. Instead, non-affiliate firms represent the only corporate structure with a positive and significant parameter, as shown in equation (6).

A third issue is the probability of generating non-imitation innovations. Equation (7) in Table 4.2 shows the regression result for non-imitation innovations (radical innovations). High and very significant parameters are found for Swedish multinationals and non-affiliate firms. For FDI firms the parameter is significant at the 10 percent level, which indicates that they are more likely to have non-imitation innovations than uninational firms.

The last equation (8) in Table A2 reflects how innovation sales are determined by our explanatory variables. In this case we find that FDI firms come out with a positive result. For FDI firms, the parameter estimate indicates that innovation sales are significantly larger than for uninational firms on a 1 percent level. At a 5 percent level Swedish multinationals and non-affiliate firms also appear to be superior to the uninational firms. We may also note that the parameter values are higher for FDI firms and domestic multinationals, and this may reflect that these two categories can base their sales success on innovation efforts in their entire multi-country network.

\section{A MATCHING ANALYSIS OF FDI FIRMS}

\subsection{Nearest Neighbour Matching Method}

Section 4 presents results based on parametric selection equations. In order to investigate the robustness of the results from these selection equations, we apply in Section 5 a semiparametric matching approach. For each FDI firm, our matching estimators find a similar (i) uninational, (ii) non-affiliate and (iii) Swedish MNE firm, respectively. In this way three sets of pairs are formed, where each FDI firm has a comparison "partner". When this is obtained we interpret the difference in their outcomes (attributes) as the effect of FDI-ownership.

Methodologically, we rely on the Rosenbaum Rubin (1983) "propensity-score” matching. The matching estimation procedure that is employed can be described as follows. Initially a probit model is applied in order to estimate the propensity score for each observation. The dependent variable expresses whether the firm is an FDI-firm or not. The vector of 
determinant variables contains the same set of characteristics as were employed in the selection equations in the previous section. After the determinants are identified and the probit model is estimated, a mono-dimensional propensity score is calculated for every observation. This measure is used to find counterfactuals for each FDI-firm.

In the next step we conduct a non-parametric matching approach based on the propensity score. Here the procedure is as follows. Firstly, the observations are separated with respect to their corporate ownership, that is FDI-firm or not. Secondly, an FDI-firm $i$ is selected. Thirdly, we utilize the propensity score and calculate a correct measure of distance to find the nearest neighbours or matched firms for each FDI firm. Finally, the impact of FDI-firms is evaluated by comparing the average outcomes between the groups of FDI-firms and non-FDIfirms.

The literature (e.g. Smith, 2000) points out that nearest neighbour matching can be operate with more than one nearest neighbour and with or without replacement. The latter means that a given non-participant observation can form the counterfactual for more than one participant. In the subsequent analysis we use the two nearest neighbours. The main advantage of a large number of neoghbours - comparet to pairwise matching - is a reduction in the variance of the estimators (Smith and Todd, 2004). Moreover, this method admits that observations without a sufficiently close are ignored. ${ }^{3}$

\subsection{Matching FDI firms against other Corporate Structure}

In Section 3 we could see indications that FDI firms might bring novelties to the local economy in Sweden. The approach in Section 4 represents a more controlled way of detecting such signs. However, the regression results in that section do not convince us that FDI firms bring new features into the innovation process in the local economy. In the subsequent analysis we compare systematically FDI firms with (i) uninational firms, (ii) non-affiliate firms, and (iii) Swedish multinationals, using the matching approach described in sub section 5.1 above.

Table 13 compares FDI firms and uninational firms with regard to mean values before and after matching. There are a set of significant differences between the two sets of firms. FDI firms collaborate more frequently in innovation networks with regard to all four innovation systems. In addition, they have larger innovation sales per employee. With lower significance value, FDI firms also are more R\&D intensive. Thus, compared with uninational firms, FDI firms should be expected to enrich the local innovation processes.

\footnotetext{
${ }^{3}$ For a more detailed description of the general methodology, see Lööf and Heshmati (2005).
} 
In particular, we observe that the product-innovation value is higher in a significant way for FDI firms. At the same time, the matched uninational firms have not a lower value for process innovations.

Table 14 compares FDI firms with non-affiliate firms. The set of FDI firms contains both small and large firms, whereas small firms dominate the group of non-affiliate firms. This may affect the matching result. At the same time, we recall that the comparison is made only across innovative firms.

For the matched sets, we observe that the FDI firms have a higher mean value than nonaffiliate firms in two regards: FDI firms have a higher proportion of newly established firms and they interact more frequently in global innovation networks.

However, there are five characteristics for which we may think of non-affiliate firms as "superior". The latter have a higher score with regard to knowledge intensity, product innovation, process innovation, non-imitation innovation and innovation sales. These five observations imply that non-affiliate firms must be considered as an important component in a region's innovation milieu. We may also recall from Table 3.6 that non-affiliate firms comprise a high proportion of knowledge-intensive service suppliers and a high proportion of low-tech manufacturing. Firms in the latter group are to large extent non-innovative firms. Thus, the subset of innovative non-affiliate firms display features that correspond to an innovation profile that is superior to the one of innovative FDI firms.

Overall these observations show that innovative non-affiliate firms form a group knowledge and technology intensive firms. As can be seen from the table, several of these latter results are not present when comparing the two populations before matching.

Our final exercise is to compare Swedish multinational with FDI firms. The result of this comparison is presented in Table 15. We may first observe that before the two populations have been matched, the difference is greater than after matching. For example, after matching the statistical difference with regard to innovation sales per employees disappears.

After completed matching we can observe that FDI firms have a lower frequency than domestic multinationals with regard to innovation collaboration in scientific, vertical and global networks, and with regard to product innovations. In addition, FDI firms have lower R\&D intensity. At a lower significance level, we may also observe a higher frequency of product innovations among the Swedish multinationals. 


\section{CONCLUSIONS}

In the previous sections we have compared the FDI firms in Sweden with other firms with the help of parametric and non-parametric methods. What can we learn from these comparisons? First, our two methods do generate consistent results. In particular, both methods reveal that the group of uninational firms are different from the other three categories of corporate structures. Uninational firms are clearly less integrated than all other firms in all types of innovation collaboration. They are less active in generating both product and process innovation, and their frequency of non-imitation innovations is lower. This is the most robust finding from the statistical analyses.

What does the literature say about the effects that FDI firms have on the local economy in which they are integrated? According to the review in Lipsey (2002) and Ebersberger and Lööf (2004)., a large number of studies report on empirical regularities that are relevant for this question. First, there is robust evidence that within countries, foreign-owned firms almost always pay higher wages than domestically-owned firms. Second, foreign-owned firms generally have higher productivity than local firms. Third, the literature does not present any strong evidence of positive impacts from FDI firms on innovation activities and output. At best, we may say that the empirical information is mixed. Fourth, there is no unambiguous support for the idea that FDI firms should affect the growth rate positively in the local economy.

This study adds a small but important piece of information to the current knowledge by making the distinction between domestic multinational, uninationals and non-affiliates in the analyses. In this way the existing statements in the literature can be qualified. Our result suggests that FDI firms may bring new elements into the innovation systems of the local economy through acquisitions of uninational firms.

Another finding, which should not be surprising, is that FDI firms are more active in global innovation networks than uninationals and non-affiliates. One should also observe that we have not included in our study the indirect effects that FDI firms may have by adding new patterns of demand for inputs of services and components, and by supplying new types of services and products as inputs into the production of domestic firms. We would need quite different data and methods to be able to illuminate this issue.

Finally, the study has an important by-product. The matching of non-affiliate firms against FDI firms reveal the former have a higher knowledge intensity, more of product, process and non-imitation innovations, and larger innovation sales per employee. This result comes out in 
the matching process, but not if we just compare average values that are affected by the large share of low-tech industries among non-affiliate firms.

It seems worth wile to further investigate the non-affiliate firms and let them be matched against all corporate structure. In such a study we may also consider how innovative nonaffiliate firms are linked to multinationals, to what extent they are the result of spin-offs and similar dynamic processes, and in which industries their innovation performance is above average. 


\section{REFERENCES}

Aitken B. and Harrison A. (1999), Do Domestic Firms Benefit from Direct Foreign Investment? Evidence from Venezuela, American Economic Review, 89:605-618.

Aitken B. and Harrison A. and Lipsey R.E. (1996) Wages and Foreign Ownership, a Comparative Study of Mexico, Venezuela and the United States, Journal of International Economics, 40:345-371.

Antras, P. \& E. Helpman (2003), “Global Sourcing”, NBER Working Paper No 10082.

Audretsch D.B. and Feldman M.P. (1996), Knowledge Spillovers and the Geography of Innovation and Production, American Economic Review, 86:630-640.

Braunerhjelm P. (1999), Knowledge Capital, Firm Performance and Network Production, JIBS Dissertation Series No 004, Jönköping International Business School.

Cantwell, J., 1998. The globalisation of technology: what remains of the product-cycle model? In: Chandler, A., Hagström, P., Sölvell, Ö. (Eds.) The Dynamic Firm. Oxford Univ. Press, New York, pp. 263-288.

Cantwell J. and Janne O. (1999), Technological Globalisation and Innovative Centres: the Role of Corporate Technological Leadership and Location Hierarchy, Research Policy, 28:119-144.

Caves R.E. (1982), Multinational Enterprises and Economic Analysis, Campbridge University Press, Cambridge.

Coase R.H. (1937), The Nature of the Firm, Economica, 4:386-405.

Criscuolo C. and Marin R. (2004), Multinationals and US Productivity Leadership: Evidence from Great Britain, STI Working Paper 2004/5.

Doms M.E. and Brandford Jensen J. (1998), Comparing Wages, Skills and Productivity between Domestically and Foreign-Owned Manufacturing Establishments in the United States, in R.E Baldwin, R.E. Lipsey and J.D. Richarfdson (eds), Geography and Ownership as Basis for Economic Accounting, Studies in Income and Wealth, 59:235-258, University of Chicago.

Dosi G. (1988), The Nature of the Innovation process, in Dosi G. et.al. (eds), Technical Change and Economic Theory, Frances Piter Publishers, London.

Dunning J. (1977), Trade, Location of Economic Activity and the MNE: A Search for an Eclectic Approach, in P-O Hesselborne, P-M Wijkman and B Ohlin (eds), The International Allocation of economic Activity, Macmillan, London, 395-418.

Ebersberger B. and Lööf H. (2004), Multinational Enterprises, Spillovers, Innovation and Productivity, CESIS Working Paper Series No 22.

Ebersberger B. and Lööf H. (2005), Innovative Bahaviour and Productivity

Performance in the Nordic Region. Does Ownership Matter?, CESIS Working Paper

Series No 27 .

Ehrnberg E. and Jacobsson S. (1997), Technological Discontinuities and Incumbents' Performance: an Analytical Framework, in C Edquist (ed), Systems of Innovation Technologies and Organisations, Pinter Publishers, London.

Freeman C. (1992), Formal Scientific and Technical Institutions in the National System of Innovation, in B. Lundvall (ed), National Systems of Innovation. Towards a Theory of Innovation and Interactive Learning, Pinter Pubishers, Lodon.

ITPS (2005a), Utländska företag - ekonomiska uppgifter 2003 (Foreign-Owned Firms Economic Data 2003), Swedish Institute for Growth Policy Analysis (ITPS), Stockholm.

ITPS (2005b), Den växande utlandskontrollen av ekonomierna I Norden (The Growing Foreign Control of the Economies in the Nordic Area), Swedish Institute for Growth Policy Analysis (ITPS), Stockholm. 
Jaffe A. Tratjenberg M. and Henderson R. (1993), Geographical Localisation of Knowledge Spillovers as Evidence by Patent Citations, Quarterly Journal of Economics, 108:577-599.

Johansson B. and Quigley J. (2004), Agglomeration and Networks in Spatial Economies, Papers of Regional Science, 83:165-176.

Johansson B. (2005), Parsing the Menagerie of Agglomeration and Network Externalities, in C Karlsson, B Johansson and RR Stough (eds), Industrial Cluster and Inter-Firm Networks, Edward Elgar, Cheltenham.

Johansson B., Lööf H. and Rader-Olsson A. (2005), Firm Location, Corporate Structure, R\&D Investment, Innovation and Productivity, CESIS Working Paper Series, No 31

Keller W. (2204), International Technology Diffusin, Journal of Economic Literature, XLII: 752-782.

Kuemmerle W. (1999), Foreign Direct Investment in Industrial Research in the Pharmaceutical and Electronic Industries - Results from a Survey of Multinational Firms, Research Policy, 28:179-193.

Lipsey R.E. (2002), Home and Host Country Effects of FDI, NBER Working Paper No 9293.

Narula R. (2002), Innovation Systems and Inertia in R\&D Location: Norwegian Firms and the Role of Systemic Lock-in, Research Policy, 31:795-816.

Nelson R. ed. (1992), National Innovation Systems: a Comparative Analysis, Oxford University Press, Oxford.

Pavitt K. and Patel P. (1999), Global Corporations and National Systsems of Innovation: Who Dominates Who?, in D Archiburgi, J Howells and J Michie (eds) Innovation Policy in a Global Economy, Cambridge University Press, Cambridge, 94-119.

Porter M. (1990), The Competitive Advantage of Nations, Mcmillan, London.

Rosenbaum, P. and D. Rubin (1983), "The central role of the propensity score in observational studies for causal effects,” Biometrica 70, 41-55.

Smith, J. (2000) "A Critical Survey of Empirical Methods for Evaluating Active Labor Market Policies,” Zeitschrift für Voilkswirtschaft und Statistik 136, 1-22.

Smith, J. and P. Todd (2004) "Does Matching Overcome Lalonde's Critique on Nonexperimental Estimators?,” Journal of Econometrics, 125 (1-2), 305-353.

UNCTAD (2004) http://www.unctad.org

United Nations (2000) “World Investment Report, 2000” United Nations Conference of Trade \& Development, New York \& Geneva, United Nations.

Zander I. (1994), The Tortoise Evolution of the Multinational Corporation-Foreign Technological Activity in Swedish Multinational Firms 1890-1990, Institute of International Business, Stockholm. 


\section{TABLES}

Table 3: Distribution of corporate structures in the sample of the study. Number of firms.

\begin{tabular}{|lllll|}
\hline Corporate structure & Stockholm & West Sweden & Rest of Sweden & Total \\
\hline Non affiliate & 194 & 197 & 498 & 889 \\
Uninational & 179 & 138 & 335 & 752 \\
Domestic MNE & 21 & 13 & 28 & 62 \\
FDI firms & 194 & 197 & 498 & 889 \\
All firms & 523 & 416 & 1148 & 2086 \\
\hline
\end{tabular}

Table 4: Share of firms in different sectors and firm entry across regions in the sample

\begin{tabular}{|lllll|}
\hline Sector groups and entry & Stockholm & West Sweden & Rest of Sweden & Total \\
\hline High-tech manufacturing & 32.5 & 15.9 & 51.6 & 100 \\
High-medum-tech manuf. & 11.8 & 22.7 & 65.5 & 100 \\
Low-medium-tech manuf. & 9.4 & 16.9 & 73.7 & 100 \\
Low-tech manufacturing & 14.9 & 23.9 & 61.2 & 100 \\
Knowl. intense services & 51.7 & 14.7 & 33.6 & 100 \\
Other services & 29.2 & 22.1 & 48.7 & 100 \\
Newly established firms & 43.5 & 18.4 & 38.1 & 100 \\
All firms & 25.0 & 19.9 & 55.1 & 100 \\
\hline
\end{tabular}


Table 5: Characteristics if innovative firms in the sample across regions

\begin{tabular}{|llll|}
\hline & Stockholm & West Sweden & Rest of Sweden \\
\hline Human capital & 29.5 & 18.5 & 15.0 \\
R\&D staff & 8.9 & 7.2 & 6.0 \\
R\&D intensity & 11.5 & 7.4 & 7.9 \\
Innovation sales (share) & 22.0 & 17.3 & 14.9 \\
\hline
\end{tabular}

Table 6: Share of firms in different sectors across corporate structure in the sample

\begin{tabular}{|llllll|}
\hline Sector groups & Non-affiliate & Uni-national & Swedish MNEs & FDI firms & Total \\
\hline High-tech manufacturing & 38.1 & 34.1 & 7.1 & 20.6 & 100 \\
High-medum-tech manuf. & 30.7 & 34.5 & 6.6 & 28.2 & 100 \\
Low-medium-tech manuf. & 43.8 & 35.7 & 2.6 & 17.9 & 100 \\
Low-tech manufacturing & 49.6 & 36.9 & 1.3 & 10.1 & 100 \\
Knowl. intense services & 46.6 & 33.3 & 3.0 & 17.0 & 100 \\
Other services & 41.1 & 40.1 & 0.7 & 18.0 & 100 \\
All firms & 42.6 & 36.0 & 3.0 & 18.4 & 100 \\
\hline
\end{tabular}


Table 7: Entry and innovativeness across corporate structure in the sample. Share of firms

\begin{tabular}{|llllll|}
\hline & Non-affiliate & Uni-national & Swedish MNEs & FDI firms & Total \\
\hline Newly established & 32.7 & 40.1 & 4.1 & 23.1 & 100 \\
M\&A & 28.8 & 46.6 & 2.4 & 22.1 & 100 \\
Innovative firms & 35.5 & 35.9 & 5.8 & 23.2 & 100 \\
All firms & 42.6 & 36.0 & 3.0 & 18.4 & 100 \\
\hline
\end{tabular}

Table 8: Knowledge and R\&D intensity and innovation sales across innovative firms.

\begin{tabular}{|lllll|}
\hline & Non-affiliate & Uninational & Swedish MNEs & FDI firms \\
\hline Human capital & 21.2 & 19.1 & 21.1 & 18.0 \\
R\&D staff & 6.5 & 6.1 & 18.1 & 6.5 \\
R\&D intensity & 9.8 & 8.4 & 15.0 & 6.2 \\
Share of innovative sales & 17.4 & 15.2 & 23.9 & 18.7 \\
\hline
\end{tabular}


Table 9: Collaboration within the innovation systems, across types of innovative firms.

\begin{tabular}{|lllll|}
\hline & Non-affiliate & Uninational & Swe.MNEs & FDI firms \\
\hline Scientific IS & 17.5 & 17.9 & 63.3 & 29.8 \\
Vertical IS & 25.4 & 23.4 & 82.2 & 34.6 \\
Horizontal IS & 17.7 & 18.4 & 54.8 & 24.5 \\
Global IS & 16.1 & 16.1 & 82.2 & 35.9 \\
\hline
\end{tabular}

Table 10: Type of innovation and knowledge protection measures across innovative firms

\begin{tabular}{|llllll|}
\hline & Non-affiliate & Uni-national & Swed. MNE & FDI firms & Total \\
\hline Product innovation & 34.9 & 31.9 & 7.9 & 25.3 & 100 \\
Process innovation & 35.9 & 34.1 & 7.0 & 23.1 & 100 \\
Non-imitation innov. & 37.8 & 28.5 & 9.8 & 24.0 & 100 \\
Patent application & 21.3 & 30.9 & 13.4 & 34.4 & 100 \\
Patent possession & 20.9 & 30.8 & 11.3 & 36.6 & 100 \\
Trade mark & 26.0 & 32.5 & 9.4 & 32.1 & 100 \\
Secrecy & 26.1 & 31.6 & 12.9 & 29.4 & 100 \\
Lead-time advantage & 29.3 & 33.2 & 10.0 & 27.5 & 100 \\
All firms & 35.2 & 35.9 & 5.8 & 23.2 & 100 \\
\hline
\end{tabular}


Table 11: R\&D and innovation activities of firms. Regression results

\begin{tabular}{|c|c|c|c|c|c|c|c|c|}
\hline \multirow[t]{3}{*}{ Equation } & \multicolumn{2}{|c|}{ (1) } & \multicolumn{2}{|c|}{ (2) } & \multicolumn{2}{|c|}{ (3) } & \multicolumn{2}{|c|}{ (4) } \\
\hline & \multicolumn{2}{|c|}{ R\&D intensity, log } & \multicolumn{2}{|c|}{$\begin{array}{c}\text { Collaboration } \\
\text { within scientific IS }\end{array}$} & \multicolumn{2}{|c|}{$\begin{array}{c}\text { Collaboration within } \\
\text { vertical IS }\end{array}$} & \multicolumn{2}{|c|}{$\begin{array}{c}\text { Collaboration in } \\
\text { horizontal IS }\end{array}$} \\
\hline & Coeff & St.err. & Coeff & St.err. & Coeff & St.err. & Coeff & St.err. \\
\hline Corp Struct. & & & & & & & & \\
\hline Swedish MNE & $0.852 * * *$ & 0.231 & $0.915^{* * *}$ & 0.200 & $1.298 * * *$ & 0.208 & $0.620 * * *$ & 0.184 \\
\hline FDI firms & 0.120 & 0.132 & 0.190 & 0.126 & $0.229 * *$ & 0.116 & 0.097 & 0.118 \\
\hline Non Affiliate & -0.122 & 0.117 & $0.239 * *$ & 0.121 & $0.215^{* *}$ & 0.109 & 0.153 & 0.112 \\
\hline Uninational & Ref & & Ref & & Ref & & Ref & \\
\hline Regions & & & & & & & & \\
\hline Stockholm & 0.082 & 0.122 & $-0.392 * *$ & 0.126 & $-0.250 * *$ & 0.113 & -0.129 & 0.114 \\
\hline West Sweden & -0.064 & 0.128 & 0.074 & 0.124 & -0.037 & 0.116 & 0.048 & 0.116 \\
\hline Rest of Sweden & Ref & & Ref & & Ref & & Ref & \\
\hline Firm attributes & & & & & & & & \\
\hline Newly establ. & -0.149 & 0.206 & -0.089 & 0.194 & 0.151 & 0.169 & 0.017 & 0.175 \\
\hline Merger \& acq. & -0.254 & 0.164 & - $0.333 * *$ & 0.148 & 0.039 & 0.134 & 0.261 & 0.129 \\
\hline R\&D inv /empl. & & & $0.129 * * *$ & 0.033 & $0.114^{* * *}$ & 0.028 & $0.119 * * *$ & 0.028 \\
\hline Persistent R\&D & $1.132 * * *$ & 0.108 & $0.736^{* * *}$ & 0.127 & $0.636 * * *$ & 0.101 & $0.608^{* * *}$ & 0.105 \\
\hline Process innov. & $0.214 * *$ & 0.097 & $0.204 * *$ & 0.096 & $0.244 * * *$ & 0.088 & $0.193^{* *}$ & 0.090 \\
\hline Employm, log & $-0.409 * * *$ & 0.040 & $0.203^{* * *}$ & 0.050 & $0.111^{* * *}$ & 0.040 & $0.180^{* * *}$ & 0.036 \\
\hline Sector dumm. & & & & & & & & \\
\hline High-tech & $0.555^{* *}$ & 0.224 & 0.235 & 0.206 & 0.169 & 0.190 & 0.029 & 0.198 \\
\hline High-medium & $0.336 * *$ & 0.170 & -0.175 & 0.159 & - 0.103 & 0.148 & -0.093 & 0.151 \\
\hline Medium-low & 0.213 & 0.178 & 0.092 & 0.165 & -0.015 & 0.149 & 0.022 & 0.154 \\
\hline Knowl. services & $1.083^{* * *}$ & 0.168 & 0.248 & 0.162 & 0.159 & 0.144 & 0.140 & 0.147 \\
\hline Other services & $1.007 * * *$ & 0.186 & -0.021 & 0.204 & -0.015 & 0.175 & 0.011 & 0.179 \\
\hline Low-tech & Ref & & Ref & & Ref & & Ref & \\
\hline Intercept & $2.658 * * *$ & 0.266 & $-2.281^{* * *}$ & 0.477 & $1.949 * * *$ & 0.340 & $-2.630 * * *$ & 0.266 \\
\hline Log likelihood & 3253 & & 1692 & & 1808 & & 1740 & \\
\hline Wald chi-square & 277 & & 94 & & 161 & & 168 & \\
\hline
\end{tabular}

Note: Significant at the $<1 \%(* * *),<5 \%(* *)$ and $\left({ }^{*}\right)<10 \%$ level of significance. Six sector dummies are included, wherelow technology manufacturing is used as reference. Number of observations is 2086, with 1015 censored observations 
Table 12: Type of innovation and innovation output. Regression results

\begin{tabular}{|c|c|c|c|c|c|c|c|c|}
\hline \multirow[t]{3}{*}{ Equation } & \multicolumn{2}{|c|}{ (5) } & \multicolumn{2}{|c|}{ (6) } & \multicolumn{2}{|c|}{ (7) } & \multicolumn{2}{|c|}{ (8) } \\
\hline & \multicolumn{2}{|c|}{ Product innovation } & \multicolumn{2}{|c|}{ Process innovation } & \multicolumn{2}{|c|}{$\begin{array}{l}\text { Non-imitation } \\
\text { innovation }\end{array}$} & \multicolumn{2}{|c|}{ Innovation sales } \\
\hline & Coeff & St.err. & Coeff & St.err. & Coeff & St.err. & Coeff & St.err. \\
\hline \multicolumn{9}{|l|}{ Corp Struct. } \\
\hline Swedish MNE & $0.970 * * *$ & 0.247 & 0.220 & 0.185 & $0.683^{* * *}$ & 0.184 & $0.650 * *$ & 0.270 \\
\hline FDI firms & $0.325^{* * *}$ & 0.112 & 0.044 & 0.106 & $0.215^{*}$ & 0.110 & $0.530 * * *$ & 0.147 \\
\hline Non Affiliate & $0.252 * * *$ & 0.097 & $0.199 * *$ & 0.095 & $0.325^{* * *}$ & 0.100 & $0.252 * *$ & 0.127 \\
\hline Uninational & \multicolumn{2}{|l|}{ Ref } & \multicolumn{2}{|l|}{ Ref } & \multicolumn{2}{|l|}{ Ref } & \multicolumn{2}{|l|}{ Ref } \\
\hline \multicolumn{9}{|l|}{ Regions } \\
\hline Stockholm & $0.240 * *$ & 0.105 & 0.121 & 0.099 & 0.095 & 0.102 & $0.489 * * *$ & 0.130 \\
\hline West Sweden & 0.149 & 0.108 & -0.053 & 0.104 & 0.154 & 0.107 & $0.237 *$ & 0.137 \\
\hline Rest of Sweden & \multicolumn{2}{|l|}{ Ref } & \multicolumn{2}{|l|}{ Ref } & \multicolumn{2}{|l|}{ Ref } & \multicolumn{2}{|l|}{ Ref } \\
\hline \multicolumn{9}{|l|}{ Firm attributes } \\
\hline Newly establ. & -0.153 & 0.155 & 0.072 & 0.152 & 0.243 & 0.154 & -0.254 & 0.257 \\
\hline Merger \& acq. & 0.100 & 0.130 & $0.333^{* * *}$ & 0.122 & -0.002 & 0.127 & 0.120 & 0.211 \\
\hline R\&D inv /empl. & 0.027 & 0.026 & $0.057 * *$ & 0.025 & $0.064 * *$ & 0.026 & $0.140 * * *$ & 0.033 \\
\hline Persistent R\&D & $0.399 * * *$ & 0.098 & -0.072 & 0.092 & 0.461 & 0.098 & 0.176 & 0.131 \\
\hline Process innov. & -0.115 & 0.081 & & & $0.239 * * *$ & 0.082 & 0.053 & 0.104 \\
\hline Employm. log & -0.044 & 0.038 & $0.131^{* * *}$ & 0.036 & -0.074 & 0.037 & $-0.360 * * *$ & 0.055 \\
\hline \multicolumn{9}{|l|}{ Sector dumm. } \\
\hline High-tech & 0.069 & 0.187 & -0.240 & 0.177 & 0.297 & 0.181 & $-0.588 * *$ & 0.289 \\
\hline High-medium & -0.006 & 0.132 & - 0.116 & 0.128 & - 0.107 & 0.133 & - 0.144 & 0.211 \\
\hline .Medium-low & 0.045 & 0.136 & 0.039 & 0.132 & 0.161 & 0.137 & - 0.359 & 0.220 \\
\hline Knowl. services & 0.090 & 0.132 & -0.017 & 0.128 & 0.078 & 0.134 & -0.319 & 0.209 \\
\hline Other services & 0.040 & 0.152 & - 0.039 & 0.151 & 0.021 & 0.158 & $0.795^{* * *}$ & 0.234 \\
\hline Low-tech & Ref & & Ref & & Ref & & Ref & \\
\hline Intercept & 0.329 & 0.322 & - $0.791 * *$ & 0.311 & - $0.655^{*}$ & 0.337 & $4.578^{* * *}$ & 0.417 \\
\hline Log likelihood & 1890 & & 1980 & & 1909 & & 3380 & \\
\hline Wald chi-square & 55 & & 38 & & 84 & & 156 & \\
\hline
\end{tabular}

Note: Significant at the $<1 \%(* * *),<5 \%(* *)$ and $(*)<10 \%$ level of significance. Six sector dummies are included, wherelow technology manufacturing is used as reference. Number of observations is 2086, with 1015 censored observations. 
Table 13: Two sample t-test results. FDI-firms versus uninational firms

\begin{tabular}{|c|c|c|c|c|c|c|c|c|c|}
\hline \multirow[b]{2}{*}{ Variables } & \multicolumn{5}{|c|}{ Before matching } & \multicolumn{4}{|c|}{ Nearest neighbour matching } \\
\hline & UNI & FDI & & & $\begin{array}{l}\text { t-test } \\
\text { value }\end{array}$ & UNI & $\mathrm{FD}$ & & $\begin{array}{l}\text { t-test } \\
\text { value }\end{array}$ \\
\hline Observations & 322 & 220 & & & & 440 & 220 & & \\
\hline \multicolumn{10}{|l|}{ Target variables } \\
\hline Newly established & 0.077 & 0.081 & & - & 0.175 & 0.050 & 0.081 & & 1.497 \\
\hline Human capital intensity & 0.197 & 0.163 & & & 1.159 & 0.149 & 0.163 & & 0.712 \\
\hline Collaboration SIS & 0.183 & 0.327 & $* * *$ & - & 3.755 & 0.204 & 0.327 & $* * *$ & 3.308 \\
\hline Collaboration VIS & 0.238 & 0.368 & $* * *$ & - & 3.197 & 0.252 & 0.368 & $* * *$ & 3.000 \\
\hline Collaboration HIS & 0.177 & 0.263 & $* *$ & - & 2.366 & 0.190 & 0.263 & $* *$ & 2.066 \\
\hline Global collaboration & 0.164 & 0.381 & $* * *$ & - & 5.592 & 0.220 & 0.381 & $* * *$ & 4.209 \\
\hline Product innovation & 0.624 & 0.722 & $* *$ & - & 2.428 & 0.609 & 0.722 & $* * *$ & -2.976 \\
\hline Process innovation & 0.484 & 0.518 & & - & 0.769 & 0.531 & 0.518 & & 0.330 \\
\hline Non-imitation innov. & 0.322 & 0.377 & & - & 1.296 & 0.325 & 0.377 & & - $\quad 1.318$ \\
\hline R\&D-intensity & 1.212 & 1.409 & & - & 1.322 & 1.172 & 1.409 & $*$ & 1.650 \\
\hline Innovation sales & 1.519 & 2.418 & $* * *$ & - & 3.553 & 1.990 & 2.418 & $* * *$ & 2.680 \\
\hline
\end{tabular}


Table 14: Two sample t-test results. Non-affiliate firms versus FDI-firms

\begin{tabular}{|c|c|c|c|c|c|c|c|c|c|c|}
\hline \multirow[b]{2}{*}{ Variables } & \multicolumn{5}{|c|}{ Before matching } & \multicolumn{5}{|c|}{ Nearest neighbour matching } \\
\hline & $\begin{array}{l}\text { Non- } \\
\text { affil. }\end{array}$ & FDI & & & $\begin{array}{l}\text { t-test } \\
\text { value }\end{array}$ & $\begin{array}{l}\text { Non- } \\
\text { affil. }\end{array}$ & FD & & & $\begin{array}{l}\text { t-test } \\
\text { value }\end{array}$ \\
\hline Observations & 322 & 220 & & & & 440 & 210 & & & \\
\hline \multicolumn{11}{|l|}{ Target variables } \\
\hline Newly established & 0.062 & 0.081 & & - & 0.860 & 0.033 & 0.085 & $* *$ & - & 2.464 \\
\hline Human capital intensity & 0.212 & 0.163 & $* *$ & & 2.207 & 0.251 & 0.167 & $* * *$ & & 4.050 \\
\hline Collaboration SIS & 0.192 & 0.327 & $* * *$ & - & 3.490 & 0.307 & 0.309 & & - & 0.060 \\
\hline Collaboration VIS & 0.263 & 0.368 & $* *$ & - & 2.551 & 0.300 & 0.362 & & - & 1.544 \\
\hline Collaboration HIS & 0.186 & 0.263 & $* *$ & - & 2.091 & 0.290 & 0.257 & & & 0.889 \\
\hline Global collaboration & 0.180 & 0.381 & $* * *$ & - & 5.143 & 0.290 & 0.380 & $* *$ & - & 2.247 \\
\hline Product innovation & 0.670 & 0.722 & & - & 1.296 & 0.807 & 0.714 & $* *$ & & 2.529 \\
\hline Process innovation & 0.521 & 0.518 & & & 0.081 & 0.580 & 0.500 & $*$ & & 1.920 \\
\hline Non-imitation innov. & 0.406 & 0.377 & & & 0.692 & 0.530 & 0.376 & $* * *$ & & 3.734 \\
\hline R\&D-intensity & 1.148 & 1.409 & $*$ & - & 1.894 & 1.211 & 1.352 & & - & 1.024 \\
\hline Innovation sales & 2.019 & 2.418 & $* *$ & - & 2.495 & 2.927 & 2.355 & $* * *$ & & 3.659 \\
\hline
\end{tabular}

Remark. Significance is marked as *** for the 1 percent level, ** for the 5 percent level and * for the 10 percent level. 
Table15: Two sample t-test results. Swedish multinationals versus FDI-firms.

\begin{tabular}{|c|c|c|c|c|c|c|c|c|}
\hline & \multicolumn{4}{|c|}{ Before matching } & \multicolumn{4}{|c|}{ Nearest neighbour matching } \\
\hline Variables & FDI & $\begin{array}{l}\text { SWE } \\
\text { MNE }\end{array}$ & & $\begin{array}{l}\text { t-test } \\
\text { value }\end{array}$ & FDI & & & $\begin{array}{c}\text { t-test } \\
\text { value }\end{array}$ \\
\hline Observations & 220 & 59 & & & 114 & 57 & & \\
\hline Target variables & & & & & & & & \\
\hline Newly established & 0.081 & 0.101 & & - 0.453 & 0.052 & 0.105 & & 1.142 \\
\hline Human capital intensity & 0.163 & 0.222 & & - 1.426 & 0.290 & 0.222 & & 1.352 \\
\hline Collaboration SIS & 0.327 & 0.694 & $* * *$ & - 5.385 & 0.473 & 0.684 & *** & 2.703 \\
\hline Collaboration VIS & 0.368 & 0.830 & $* * *$ & - 7.826 & 0.464 & 0.824 & $* * *$ & 5.199 \\
\hline Collaboration HIS & 0.263 & 0.542 & $* * *$ & - 3.878 & 0.412 & 0.526 & & 1.404 \\
\hline Global collaboration & 0.263 & 0.542 & $* * *$ & - 3.878 & 0.508 & 0.842 & $* * *$ & 4.492 \\
\hline Product innovation & 0.722 & 0.915 & $* * *$ & - 4.056 & 0.824 & 0.912 & $*$ & - 1.685 \\
\hline Process innovation & 0.518 & 0.610 & & - 1.270 & 0.543 & 0.596 & & 0.653 \\
\hline Non-imitation innov. & 0.377 & 0.627 & $* * *$ & - 3.497 & 0.570 & 0.631 & & 0.771 \\
\hline R\&D-intensity & 1.409 & 2.282 & $* * *$ & - 3.618 & 1.663 & 2.215 & ** & - 2.061 \\
\hline Innovation sales & 2.418 & 3.054 & $* *$ & -2.345 & 2.561 & 2.991 & & - 1.535 \\
\hline
\end{tabular}




\section{APPENDIX: LIST OF VARIABLES}

Table A: Primary variables for the empirical analyses

\begin{tabular}{|c|c|}
\hline ExplonatoryExplanatory variables & Definition \\
\hline \multicolumn{2}{|l|}{ Firm structure } \\
\hline Non Affiliated Enterprises & Domestically-owned firms without affiliates \\
\hline Uninational Enterprises & $\begin{array}{l}\text { Domestically-owned firms belonging to a group with only } \\
\text { Swedish affiliates }\end{array}$ \\
\hline Domestic Multinational Enterprise & $\begin{array}{l}\text { Domestically-owned firms belonging to a group with foreign } \\
\text { affiliates }\end{array}$ \\
\hline FDI Enterprises & Foreign-owned firms (belonging to a group) with \\
\hline \multicolumn{2}{|l|}{ Firm characteristics } \\
\hline Size & Number of employees \\
\hline Productivity & Turnover per employee \\
\hline Human capital & Share of the employment with a university degree \\
\hline Physical capital & Gross investment \\
\hline Innovation input & Innovation expenditures (R\&D intensity) \\
\hline Persistent R\&D & Dummy for continuous R\&D engagement \\
\hline Process innovation & $\begin{array}{l}\text { Dummy variable indicating that a firm has introduced a new } \\
\text { or significantly improved process }\end{array}$ \\
\hline Non-imitation innovation & Dummy indicating that new products have been introduced \\
\hline Newly established & $\begin{array}{l}\text { The enterprise has been established during the last three } \\
\text { years }\end{array}$ \\
\hline $\begin{array}{l}\text { Recent history of merging and } \\
\text { acquisition }\end{array}$ & $\begin{array}{l}\text { The enterprise has been involved in M\&A during the last } \\
\text { three years }\end{array}$ \\
\hline \multicolumn{2}{|l|}{ Collaboration on innovation } \\
\hline $\begin{array}{l}\text { Embeddedness in the regional science } \\
\text { base }\end{array}$ & $\begin{array}{l}\text { Dummy indicating collaboration with universities and R\&D } \\
\text { laboratories }\end{array}$ \\
\hline $\begin{array}{l}\text { Embeddedness in the regional vertical } \\
\text { innovation system }\end{array}$ & $\begin{array}{l}\text { Dummy indicating innovation collaboration with customers } \\
\text { or suppliers }\end{array}$ \\
\hline $\begin{array}{l}\text { Embeddedness in the regional } \\
\text { horizontal innovation system }\end{array}$ & $\begin{array}{l}\text { Dummy indicating innovation collaboration with } \\
\text { competitors and consultants }\end{array}$ \\
\hline $\begin{array}{l}\text { Embeddedness in global innovation } \\
\text { systems }\end{array}$ & $\begin{array}{l}\text { Dummy indicating innovation collaboration in a cross- } \\
\text { border network }\end{array}$ \\
\hline \multicolumn{2}{|l|}{ Market } \\
\hline Significant market area - local & The firms' most significant market \\
\hline Significant market area - national & The firms’ most significant market \\
\hline $\begin{array}{l}\text { Significant market area - global } \\
\text { Sector }\end{array}$ & The firms’ most significant market \\
\hline High technology manufacturing sector & Nace 353, Nace 2423, Nace, 30, Nace 32, Nace 33 \\
\hline Medium high technology manuf. sectors & $\begin{array}{l}\text { Nace } 24 \text { excl Nace 2423, Nace 29, Nace 31, Nace 34, Nace } \\
\text { 352, Nace } 359\end{array}$ \\
\hline Medium low technology manuf.sectors & $\begin{array}{l}\text { Nace 23, Nace 25, Nace 26, Nace 37, Nace 28, Nace 351, } \\
\text { Nace } 354\end{array}$ \\
\hline Low technology manufacturing sectors & $\begin{array}{l}\text { Nace } 15 \text {, Nace } 16 \text {, Nace } 17 \text {, Nace } 18 \text {, Nace } 19 \text {, Nace } 20 \text {, } \\
\text { Nace } 21 \text {, Nace } 36 \text {, Nace } 37\end{array}$ \\
\hline Knowledge intensive services & Nace 64, Nace 65, Nace 66, Nace 67, Nace 71, Nace 72-74 \\
\hline Other services & Other services than Knowledge intensive services \\
\hline
\end{tabular}

